\title{
Theoretical highlights in container port logistics systems
}

\author{
Arbia Hlali \\ Department of Economics, Faculty of Economics and \\ Management Science of Sfax, Tunisia \\ arbiaarbiahlali@yahoo.fr
}

\author{
Abdulla Wanis \\ Maritime Postgraduate Studies Institute, Arab Academy for \\ Science, Technology \& Maritime Transport, Alexandria, Egypt \\ The Higher Institute of Marine Sciences Technologies, Sabratha, \\ Libya \\ nouraw@gmail.com
}

\section{Abstract}

This study provides a theoretical background on container port logistics in global supply chains. A descriptive analysis including a literature review was carried out in order to achieve the study. This study shows that the container port logistics chain involves all levels of organizational units throughout the supply chain. Therefore, it ensures coordination and exchanges in terms of physical flows, financial flows and informational flow in such a way that the goods are handled and distributed in the right kind. In addition, the analysis finds that the logistics chain required to be evolved with the international changes of maritime transport in order to keep the competitive of seaport. Thus, there is a need to optimize all seaport activities to attain the benefits of the logistics chain. Moreover, this study contributes to the field by exploring the container port logistics integration concept. One of the important findings of this study is that the port is central to logistics - the multidimensional system with a complex activities. Consequently, the findings are relevant to all actors such as transport companies and logistics service providers.

\section{Keywords}

Seaport logistics system, supply chain, container port

\section{Introduction}

Transport plays a significant role as an agent of globalization. Thus, it is considered as being one of the four cornerstones of globalization together with trade liberalization, telecommunications and international standardization (Abdulla, 2018). The growth of transport activities is linked to the economic globalization of which it is both the 
consequence and the support. The acceleration flow of goods modifies the strategies of the actors in terms of supply, demand and regulation.

Seaports are affected by a variety of developments in the economic, the technological and the geopolitical sectors. The shifts in the global production and the international trade affect the port activity level and the port function, especially with regard to the container ports. The logistics become an important element for the success and smooth operation of maritime transport processes. The evolution of logistics and its actors are resulted in their mode of communication. Indeed, transport operations as well as logistics require very significant costs. In addition, the global supply chains deliver a connectivity between markets, labour, parts and resources to ensure the production and the consumption by maintaining the service level (Notteboom and Rodrigue, 2017). On the other hand, supply chain models evolve continuously as a result of influences and factors such as globalization and expansion into new markets. Service expectations of customers are moving towards a push for higher flexibility, reliability, and precision (Rodrigue et al., 2020).

Correspondingly, to the others changes, seaports have evolved through several generations (Paixao and Marlow 2003; Martin-Castilla and Rodrigo 2003; Beresford et al. 2004; Bisgaard 2008). In broad terms, until the 1960s, the ports were the interfaces between the terrestrial link and the maritime link of the transport of goods, and studies (Paixao and Marlow 2003; Beresford et al. 2004) describe this period as the first generation of seaports. From this time until the 1970s seaports constituted a center of transport and industrial and commercial activities and were known as the second generation of seaports. Seaport activities however, became more integrated with the transport center system for the international trade in the third generation to being a logistics platform (Hayes, 2002).

Recently, and up to the 2000s, the seaport has become a logistics network and supply chain, commonly referred to as the fourth generation of seaports (see Notteboom and Winkelmans 2001; Carbone and De Martino 2003; Cuadrado et al. 2004; Heaver 2006; Rodrigue and Notteboom, 2008). The concept of the fifth generation itself defines the seaport as the integrated supply chain which has become more independent and active. As well, the quality of service has adapted to the needs and requirements of the customers and stakeholders (Lee and Lam, 2014; Hlali and Hammami, 2017). Thus, for the fifth generation, the seaport became a community- rather than a logistics hub.

Similar to those who study the development of port generations, some authors are more interested in logistics system, for instance, Notteboom and Rodrigue (2009) who focus on the current and the future port development tendencies. They take account of the trends on the containerized cargo transport and logistics system effectiveness as well as the global supply chains. Bae (2012) studied the importance of integrated logistics factors which affecting customer service and can add value to port logistics system. Also, Ascencio et al., (2014) conceived the collaboration of the logistics framework for a Port Logistics Chain (PLC) based on the Supply Chain Management (SCM) principles, while Wang et al., (2014) set a methodology for analyzing the port logistics process applied to a Chinese bulk port.

Most recently, some intentions are focused in the seaport and the digital technologies. Sanchez-Gonzalez et al., (2019) developed a literature review in the digital technologies and the maritime transport sector as Design and Shipbuilding, shipping and seaports. Elsaih and Salem (2018) proposed a theoretical analysis for horizontal integration of container ports in the Mediterranean region. However, Agatić and Kolanović, (2020) concluded that the digitization influenced the seaport and the seaport service. 
The review of literature displayed that the study of the container port logistics is insufficiently developed theoretically or practically. Thus, this study aims to introduce a theoretical framework in the container port logistics system - despite this main objective of this study, it is also aims to highlight the different background of container port logistics. Specifically, the examination of the seaport port logistics context, such as the role and the function, the chain process, the chain flows and the logistics integration. Accordingly, in order to achieve study, the paper was organized in seven sections in the following manner. The First Section represents the introduction with a literature review on container port logistics. Section Two discusses the role of container port in the logistics supply chain. The third section provides an explanation on the logistics chain flows. The Fourth Section presents logistics integration in the maritime industry and their main levels, while the Fifth Section describes the logistics integration in the maritime industry and their main levels. The Sixth Section discusses the impact of the logistics chain on the maritime transport and the seaport, which leads to improve the productivity and performance of port activities. The Seventh section presents the conclusion.

\section{Role of container Port in the logistics supply chain}

The perimeter of a supply chain is defined according to the nature of its context (Corominas, 2013) and the companies may be located in more than one geographical location. Thus, the container terminal is considered as a sensitive link in the port logistics chain. It is a complex system where the handling and transport of containers play a crucial role (Henesey, 2006). In addition, the performance of the terminals depends on both strategic and tactical operational decisions which made by different levels of port managers through logistics chain.

Any process would be defined as a logical sequence of activities over time in order to achieve goal(s) by transforming input elements into output elements (Davenport and Short, 1990 and Harrington, 1991). In the port logistics chain several processes are combined to deliver the goods to their final customers. Figure 1 below depicts the main processes for port pre- and post-shipments goods from the origin to the final destination.

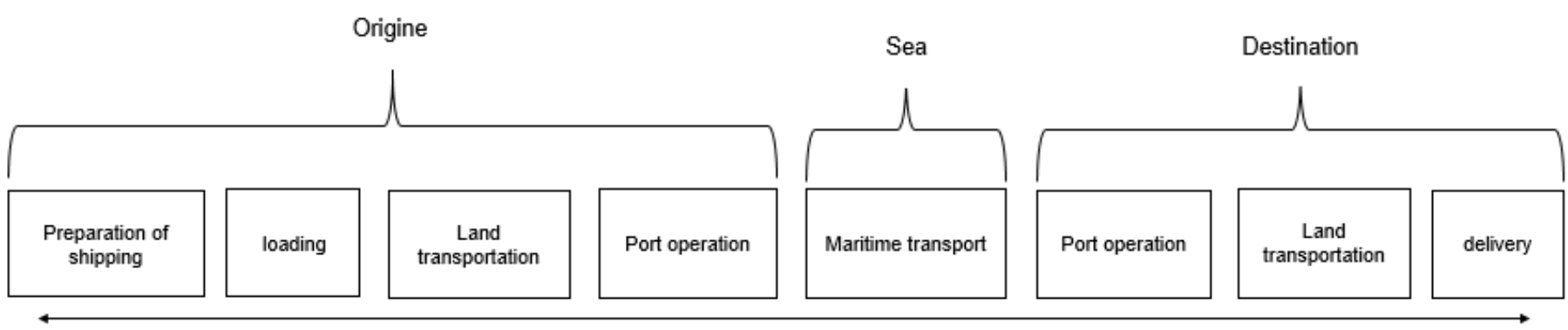

Supply chain logistics

Fig 1. Role of ports through logistics supply chain. (Source: authors' elaboration).

Figure 1 illustrates how the effective logistics chain constitutes a critical element in the competitiveness of international shipping operations chain from producer to the final consumer. Sometimes various difficulties arise from poor coordination of any uncoordinated schedules, customs delays, insufficient information on delays and inconsistent standards. For this reason, logistic services help to solve these problems to their customers or stakeholders in order to reduce transport costs, and the proportion of empty trips by promoting the exchange of information between carriers as well as organizing over all operations (Havenga, 2015 and Islam, 2017). 
Transport logistics survey a flow of the management system. Therefore, it required a systematic organizational approach. All goods must be processed before being transported. Hence, the goods must be packaged, labeled and marked for more identification and more facilitation without any difficulty. In maritime transport, the packaging and packing of the goods (cargo) is the shipper's responsibility. The packaging intended to protect the goods during transport, handling and storage.

The risks in the sea transport include several factors such as losses, sinking and damage. The implementation of an export/import requires the consent of both parties (buyer and seller). This agreement usually materializes in an international sales contract (Murray, 1991). Further, throughout the international freight chain, there are several responsibilities between the carrier, the shipper and the consignee. It applied depending on the terms of the contract or even the incoterms. From this angle, distribution of costs intervenes to define the responsibilities of each one to avoid any conflict (Spekman and Davis, 2004; Christopher, 2005). Moreover, the achievement of this contract following the necessary costs allocation stages before boarding until the delivery of the goods to the destination.

Nowadays, due to the complex nature of a port from a managerial and an entrepreneurial point of view that driven by digitalization and the introduction of green logistics and the fifth generation (5GP) concepts. The evolution of international maritime trade patterns rises the new generation port (Fourth 4GP and 5GP). Consequently, make changes the ports to a dynamic node in the international production and distribution network. The claim that a container port gained the status of a crossroad between the production and the distribution spheres calls for the integration with the main customers, both port direct users and final clients. Consequently, service providers in logistics, shipping and ports will empower the supply chain with the support of intelligent transport systems. Added to this, ports and logistics service providers have to focus on supply networks.

\section{The logistics chain flows}

The major challenge for any business is to remain competitive. To achieve this objective, it is necessary to manage its flows at minimum costs to satisfy the customers. In this vein, the performance of logistics chain is highly depending on coordination between its actors. Also, control of the logistics chain requires a good control of the different flows within this chain. Overall, these flows are classified into three types, and as shown in the Figure 2. That are information, physical and financial flows, and any organization that participates in the circulation of these different flows is considered as a link or a player in the supply chain.

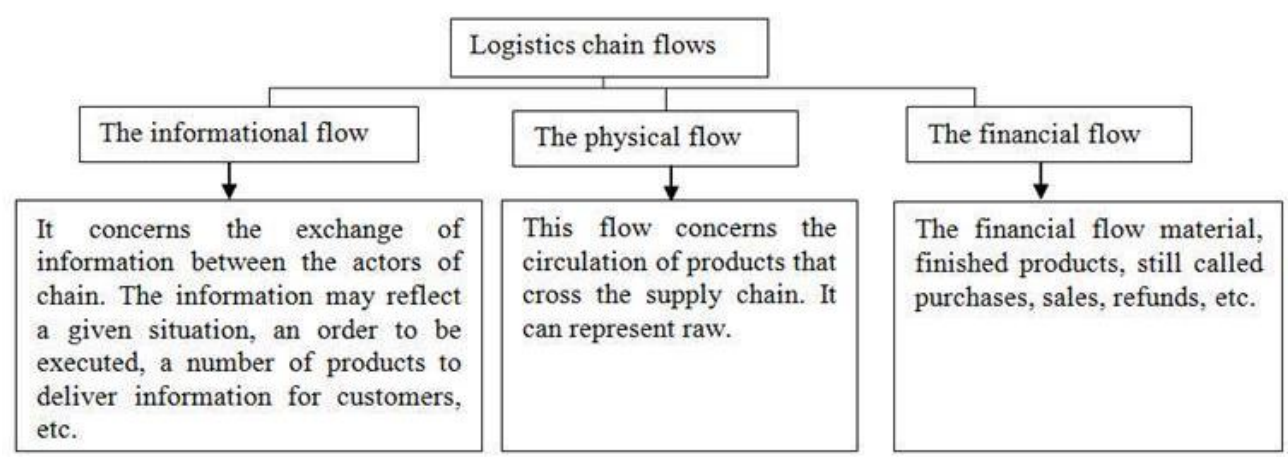

Fig 2. Logistics chain flow (Source: Authors' elaboration derived from various sources) 


\section{Logistics integration in the maritime industry and their main levels}

The integration of container terminals in the global supply chains has improved the performance and the competitiveness of the container ports which benefit from it. Indeed, there are several objectives of container port logistics integration. In this context, Notteboom and Rodrigue (2005) proven that the port logistics integration had improved the relationship between ports in a region. Whereas, Notteboom (2008) who studied the integration between terminal operator and logistics, found that the terminal operators are excited to integrate terminals into supply chains and shipping companies which need a long period to be accomplished. Accordingly, the main difficulties with the integration of terminal operators is the sittings of the strategic development to ensure the integration of all terminal operators.

Similarly, Song and Panayides (2008) studied that the port logistics integration is dependent from the coordination and the relationship between the different actors of port logistics. In another study, Panayides and Song (2009) trait that the port logistics integration assume collaboration of logistics system function and other port systems with integration of supply chain practices. Wilmsmeier et al., (2015) studied the integration between port and hinterland with examination of the development of inland ports and the analysis of port of Veracruz port one of the main container terminal in Mexico.

Regarding the levels (stages) of integration of container ports, it needs to be re-defined and restructured in order to encompass the modern global reality for the maritime industry and ports in particular (Burns M.,2015) and these levels are:

Level I: The supply chain consists of different corporate entities and divisions, such as; port strategy and operations are formed on the basis of the company's resources. The absence of information exchange creates lack of visibility throughout the logistics process,causing delays and poor outcome.

Level II: The organization applies internal integration, aiming at profit maximization and obtaining low-cost factors of production. The company lacks long-term visibility, and communication is not used effectively in order to attune to the supply chain's goals and objectives.

Level III: Corporate integration is focused on the port's territories. The port interacts with clients and its supply chain partners only in regard to operations, time, services, and activities that affect the port. Interdepartmental collaboration and information exchange have been achieved, and the port has achieved a holistic strategy.

Level IV: The port attains external integration throughout the entire supply chain. This new corporate attitude enables the port to expand its vision throughout the markets, manufacturers, terminal and liner operators, and other clients.

Level V: The external integration expands from a supply-chain level to a regional, national, or global level. The port authorities purpose to increase the port's bargaining power by designing long-term strategies. With a keen understanding that the port's power within the current supply chain may be influenced by other. 


\section{Complexity of logistics seaport function}

The seaport is a multidimensional system with a complex activities. Therefore, the port can be considered as a center of logistics (Montwiłt, 2014). Thus, there is a difference between port in implementation, management organization and technologies which need a transition to maintain the integration and the cooperation between their activities and the other connecting seaports (Jović et al, 2019). Generally, the complexity and evolution of Supply chain distribution follows one or more of the following scenarios:

- Type 1: point-to-point network: even distribution of power.

- Type 2: hub-and-spoke network: the hub has increased bargaining power over the spokes.

- Type 3: interactive hub-and-spoke networks: terminal operators, shippers, and manufacturers merge, and coordinate multiple networks.

- Type 4: holistic networks: a large-scale lean and agile system.

In the real case, when a container ship arrives at the port, it begins with the container handling by the quay cranes. The containers are then transferred by vehicles/straddles traveling between the vessel and the storage area. This stack of discharged containers consists of a certain number of lanes, where containers can be stored temporarily for a tiny period. The tracks are served by machines, such as cranes, chassis, straddles and forklifts can transport containers to the container yard for stacking. After a short period at container yard/storage area, the containers leave to the end customers via different modes of transport; barges, ships, trucks or trains.

Regarding the direction of container export, containers arrived to the port by truck, train or barge. They are then distributed among the blocks of the storage area. Before it loaded from the storage area with gantries (Yard Cranes) or straddles in order to transport them by internal transfer vehicles (Yard Truck/chassis) to the quay/jetty where it handled by quay cranes (Quay Cranes) and deposited on ship's slots. Moreover, the logistics of container terminals poses several decision problems (Henesey, 2006). Thus, for this reason, the decisions can be made in each strategic, operational or tactical level, and the logistics operations become much more complex due to the technology changes.

\section{The impact of logistics chain on the maritime transport and the seaport}

According to Panayides and Song (2013) the maritime logistics performance emphases on the performance criteria in the port sector. Therefore, the impacts of maritime logistics matches to the activities closely and related to the port activities. All ports' professions are related to the services/activities that provided to the ships and to the goods namely; transport during loading, unloading / discharging, storage: bunkering, mooring, towing, handling, warehouses, maritime insurance and customs forwarding services of the port. Moreover, the logistics integration improved the port efficiency within the quality services and the value added services.

In addition, the logistics chain matches to the activities of which a part raises of turnover is connected with the port. Generally, there are many interventions in the logistics systems which make it more importance for maritime transport; ship types, the types of goods/cargo and the natures of goods itself. Subsequently, the impacts of maritime logistics which present at all levels of port operation can be divided into two main categories. 
First, a direct impact matches to the activities closely and related to the maritime-port activity, the one whose very existence is linked to the ports. Second, an indirect impact matches to the activities of which a part raises of turnover is connected with the port (companies which use the port for their imports and their exports). To this end, there are generally many interventions in the logistics systems which make it more importance for maritime transport; ship types, the types of goods/cargo and the natures of goods itself. Table 1 below describes the three main interventions and characteristics of logistics systems.

Table 1. Logistics system characteristics and interventions

\begin{tabular}{|c|c|c|}
\hline Ship types & Cargo types & Nature of goods \\
\hline $\begin{array}{l}\text { Generally, ships are classified into two } \\
\text { types which are: specialized vessels } \\
\text { and non-specialized vessels. } \\
\text { Specialized vessels: These vessels } \\
\text { are reserved for the transport of a } \\
\text { particular type of cargo, their } \\
\text { characteristics (draft, length, breadth, } \\
\text { and depth) depend on the exclusivity, } \\
\text { specificity and the nature of the } \\
\text { goods that to be transported, for } \\
\text { instance: oil tankers, bulk carriers, } \\
\text { cellular container ships and pipeline } \\
\text { and heavy-lifts... etc. } \\
\text { Non-specialized vessels: intended to } \\
\text { carry all types of goods. It is } \\
\text { distinguished according to their } \\
\text { handling. Their characteristics } \\
\text { include: length, width, depth and draft. } \\
\text { These vessels are classified } \\
\text { according to their main handling } \\
\text { means. For example: conventional } \\
\text { cargo ships, non-cellular container } \\
\text { ships, Ro-Ro ships, Lo-Lo ships and } \\
\text { chemical carriers... etc. }\end{array}$ & $\begin{array}{l}\text { Marine cargo are classified into two } \\
\text { broad parts which are: general cargo } \\
\text { and bulk goods. } \\
\text { General cargo is that which is } \\
\text { packaged and packed in pallets, } \\
\text { crates, boxes, containers or stowed. } \\
\text { In addition, its transport does not } \\
\text { depend on its packaging, but rather its } \\
\text { physical appearance. The ships that } \\
\text { carried the general cargo are the } \\
\text { multipurpose ships. } \\
\text { Bulk cargo includes products that are } \\
\text { transported directly in the ship holds. } \\
\text { Bulk cargo generally includes solid } \\
\text { bulk and liquid bulk. }\end{array}$ & $\begin{array}{l}\text { There are several types of goods: } \\
\text { perishable products, dangerous } \\
\text { products and fragile products. } \\
\text { Perishable Products: These types of } \\
\text { products are transported with special } \\
\text { equipment, such as insulated } \\
\text { equipment, whether or not equipped } \\
\text { with a thermal device, refrigerants, } \\
\text { refrigerators or heat. } \\
\text { Hazardous and Fragile Products: } \\
\text { these products include weapons, fuels } \\
\text { and explosives, any other combustible } \\
\text { or radioactive agents... etc. Anything } \\
\text { that can cause damage, damage } \\
\text { and/or harm to people's health is } \\
\text { classified as dangerous goods. }\end{array}$ \\
\hline
\end{tabular}

Source: Authors elaboration derived from various sources.

Furthermore, the competitive advantages of logistics development are forcing port authorities today to strengthen their specific and operational goals, in order to set ports as key points in the transport chain while optimizing their intermediate functions. The goals of the port logistics are the optimization of goods' flows, the effective harmonization 
between the port agents and the activities regularization and the stimulation of commercial competition. Subsequently, the port is a central logistics point. It implies the following additional goals:

- The organization of spaces and port infrastructures from the point of view of their logistic objective;

- The rental and the concession of the different spaces necessary for the implementation of a logistic activities area;

- The active participation by specialists in the full use of the port area and facilities such as logistic activity areas (shipping agents, logistic operators, etc.)

Logistics in general and particularly container port logistics use new rules of production management to optimize the profitability of the port platform.

\section{Conclusion}

This study is based on literature review using descriptive analysis. It illustrated how much the container port logistics is essential for the smooth operation of any business. As well as this, it emphasises mainly on how to manage the flow of containerized goods through the logistics chain. The analysis of literature suggests that container port logistics should evolve with the international changes and improvements occurred in the maritime sector to keep on it competitive. Obviously, this study provided a theoretical backgrounds of container port logistics in the global supply chains. These backgrounds were developed the role of container port in the logistics supply chain, the logistics chain flows, the logistics integration in the maritime industry and their main levels. Moreover, it discussed the complexity of logistics seaport function and the impact of the logistics chain on the maritime transport and the seaport.

The main findings of this study are as the following: first, the seaport as a complex system requires a global process logistics system. In broad terms, the port logistics system usually includes three flow steps which integrate with each other. The first two are interested to the information and the physical flow while the third one is related to the infrastructure and other resources. This analysis is similar to the study of Tseng et al. (2005a) which showed that the logistics flows assume to an efficient logistics operations mean a connected relationship between all steps. Second, it illustrated the differences interventions of the logistics chain system in all the container port levels can find a preferment system. Third, as the seaport is a multidimensional system characterized by a complex activities, the logistics integration improved the matching between seaport activities and actors top optimize the port management. Lastly, this study contributed by introducing of a conceptual framework in container port logistics integration context by exploring the different level of integration within the actors as shipping lines, port authorities, transport companies, logistics service.

Furthermore, it is important to note that cooperation between supply chain partners and integrated data solutions is the key to achieve that, while more horizontal collaboration between ports and transport companies, and logistics service providers are needed to deal with the need for shorter, convenient, more sustainable, and cost-efficient supply chains (Notteboom et al., 2020). Thus, further research can discuss and develop the vertical and horizontal supply chain integration in container port, and illustrate the synergy between the different actors according to the integration level. 


\section{References}

Abdulla, W.2018. 'Global container shipping in a changing economic world; recent trends and future perspectives', MARLOG Conference, Round 6, Alexandria, Egypt. https://doi.org/10.13140/RG.2.2.16894.69445

Alfalla-Luque, R, Medina-Lopez, C \& Dey, PK.2013. Supply chain integration framework using literature review, Production Planning \& Control, vol. 24, no. 8-9 :800-817. https://doi.org/10.1080/09537287.2012.666870

Agatić, A. Kolanović, I.2020. Improving the seaport service quality by implementing digital technologies, Scientific Journal of Maritime Research 34: 93-101. https://doi.org/10.31217/p.34.1.11

Ascencio, L. M., González-Ramírez, R. G., Bearzotti, L. A., Smith, N. R. and Camacho-Vallejo, J. F. 2014. A collaborative supply chain management system for a maritime port logistics chain. Journal of Applied Research and Technology.12:444458.https://doi.org/10.1016/S1665-6423(14)71625-6

Elsaih. M, Salem. K-M. 2018. The Impact of Horizontal Integration on Mediterranean Container Port Competitiveness. International Journal of Scientific \& Engineering Research. 9(9). Available at: https://www.ijser.org/researchpaper/The-Impact-of-Horizontal-Integration-onMediterranean-Container-Port-Competitiveness.pdf. Last accessed: 15/11/2020

Bisgaard, S. 2008. Quality management \& Juran's legacy, Quality Engineering. 20:390-401. https://doi.org/10.1080/08982110802317398

Beresford, A., Gardner, B., Pettit, S., Naniopoulos, A. \& Wooldridge, C. 2004. The UNCTAD and WORKPORT models of port development; evolution or revolution? Maritime Policy and Management. 31:93-107. https://doi.org/10.1080/0308883042000205061

Bae, H. S.2012. Tue influencing factors of logistics integration and customer service performance for value creation of port logistics firms, The Asian Journal of Shipping and Logistics. 28(3):345-368. https://doi.org/10.1016/j.ajsl.2013.01.004

Burns, M. 2015. Port management and operations. Taylor \& Francis Group, LLC. https://doi.org/10.4324/9781315275215

Christopher, M and Lee, H.L. 2004. Mitigating supply chain risk through improved confidence. International journal of physical distribution \& logistics management. 34(5):388-396. https://doi.org/10.1108/09600030410545436

Coronado Mondragon, A. E.; Lalwani, C. S.; Coronado Mondragon, E. S; Coronado Mondragon, C. E.; Pawar, K. S. 2012. Intelligent transport systems in multimodal logistics: A case of role and contribution through wireless vehicular networks in a seaport location. International Journal of Production Economics.137:165-175. https://doi.org/10.1016/j.ijpe.2011.11.006

Carborne, V. \& De Martino, M. 2003. The changing role of seaports in supply chain management: an empirical analysis. Maritime Policy and Management.30(4):305-320. https://doi.org/10.1080/0308883032000145618

Cuadrado, M., Frasquet, M. \& Cervera A. 2004. Benchmarking the port services: a customer oriented proposal. Benchmarking.11(3):320-330. https://doi.org/10.1108/14635770410538781

Corominas, A., 2013. Supply chains: what they are and the new problems they raise. International Journal of Production Research. 51:68286835. https://doi.org/10.1080/00207543.2013.852700

Davenport, T., \& Short, J. 1990. The new industrial engineering; information technology and business process redesign. Sloan Management Review.31 (4):11-27. Available at: https://sloanreview.mit.edu/article/the-new-industrial-engineering-information-technology-and-businessprocess-redesign/. Last accessed: 15/11/2020

Daniel E. Murray, 1991. Risk of Loss of Goods in Transit: A Comparison of the 1990 Incotems with Terms kom Other Voices, 23, Inter-American. Rev. 93. Available at: http://repository.law.miami.edu/umialr/vol23/iss1/4 Last accessed: 04/11/2020.

Dawidowicz, L.F., Postan, M. 2015. The directions of the service development of European seaports specializing in handling perishable goods. Ekonomiczne Problemy Usług 119:85-98. DOI: 10.18276/epu.2015.119-06 
Havenga, J.H. 2015. Macro-logistics and externality cost trends in South Africa. Underscoring the sustainability imperative. International Journal of Logistics Research and Applications. 18:118-139. https://doi.org/10.1080/13675567.2015.1015509

Hlali, A. and Hammami, S. 2017. Seaport Concept and Services Characteristics: Theoretical Test, the Open Transportation Journal.11:120-129. DOI: $10.2174 / 1874447801711010120$

Henesey, L. 2006. Multi-agent systems container terminal management. Doctorat thesis. Blekinge Institute of Technology. Available at: https://www.diva-portal.org/smash/get/diva2:837142/FULLTEXT01.pdf. Last accessed: 15/11/2020

Hayes, John, 2002. 'Global Trends of Logistics Services in Port Areas', paper presented at the Regional Seminar on Commercial Development of Ports as Logistics Centres, Bangkok, Thailand, July.11-12.

Harrington, H. 1991. Business Process Improvement - The Breakthrough Strategy for Total Quality, Productivity, and Competitiveness. New York: McGraw-Hill. Available at: https://lib.ugent.be/catalog/rug01:000739510. Last accessed: 15/11/2020

Heaver, T. 2006. The evolution and challenges of port economics, in Port Economics: K. Cullinane an Imai, A., Sasaki, K., Nishimura, E. 2006. Multi-objective simultaneous stowage and load planning for a container ship with container rehandle in yard stacks, European Journal of Operational Research. 171:373-390. doi:10.1016/S0739-8859(06)16002-3

Jović, M. Kavran, N. Aksentijević, S. and Tijan, E. 2019. The Transition of Croatian Seaports into Smart Ports. 42nd International Convention on Information and Communication Technology, Electronics and Microelectronics (MIPRO), Opatija, Croatia. p:1386-1390.DOI:

10.23919/MIPRO.2019.8757111

Lee, P. Lam, J. 2016. Developing the Fifth Generation Ports Model, (in:) Dynamic Shipping and Port Development in the Globalized Economy, ed. P. Lee, K. Cullinane, Palgrave Macmillan, London.p.188. https://doi.org/10.1057/9781137514233_8

Martín-Castilla, J.\& Rodríguez-Ruiz, O. 2003. EFQM model: knowledge governance and competitive advantage. Journal of Intellectual Capital. 9(1):133-156. https://doi.org/10.1108/14691930810845858

Montwitt, A. 2014. The role of seaports as logistics centers in the modelling of the sustainable system for distribution of goods in urban areas, 1st International Conference Green Cities 2014 - Green Logistics for Greener Cities, Procedia - Social and Behavioral Sciences,151:257-265. https://doi.org/10.1016/j.sbspro.2014.10.024

Notteboom, T. \& Winkelmans, W. 2001. Structural changes in logistics: how will seaport authorities face the challenge. Maritime Policy and Management. 28 (1):71-89. https://doi.org/10.1080/03088830119197

Notteboom, TE \& Rodrigue, J-P. 2005. Port regionalization: towards a new phase in port development. Maritime Policy \& Management. 32 (3):297-313. https://doi.org/10.1080/03088830500139885

Notteboom, TE. 2008. The relationship between seaports and the inter-modal hinterland in light of global supply chains, International transport forum. https://doi.org/10.1787/9789282102251-en

Notteboom, TE. Rodrigue, JP 2009. The future of containerization: perspectives from maritime and inland freight distribution, Geo.journal, vol. 74, No. 1. https://doi.org/10.1007/s10708-008-9211-3

Notteboom, T. and Rodrigue, J.P. 2017. 'Re-assessing port-hinterland relationships in the context of global commodity chains', in Wang, J. et al. (Eds.): Ports, Cities, and Global Supply Chains. 67-82. Available at:https://www.taylorfrancis.com/books/e/9781315246376/chapters/10.4324/9781315246376-13. Last accessed: 15/11/2020

Notteboom, T. Pallis A. and Rodrigue JP., 2020. Port Economics, Management and Policy, New York: Routledge. Available at: https://porteconomicsmanagement.org/. Last accessed: 15/11/2020

Paixao, A. \& Marlow P. 2003. Fourth generation seaports - A question of agility? International Journal of Physical Distribution and Logistics Management. 33 (4): 355-376. https://doi.org/10.1108/09600030310478810

Panayides, PM \& Song, D-W. 2008. Evaluating the integration of seaport container terminals in supply chains', International Journal of Physical Distribution \& Logistics Management. 38(7):562-584. https://doi.org/10.1108/09600030810900969 
Panayides, PM \& Song, D-W. 2009. Port integration in global supply chains: measures and implications for maritime logistics, International Journal of Logistics: Research and Applications. 12(2):133-145. https://doi.org/10.1080/13675560902749407

Panayides, P. M., \& Song, D.-W. 2013. Maritime logistics as an emerging discipline. Maritime Policy \& Management. 40(3):295-308. https://doi.org/10.1080/03088839.2013.782942

Rodrigue, J. \& Notteboom, T. 2008. The terminalisation of supply chains, in Proceedings of the IAME 2008 Conference, Dalian, China.https://doi.org/10.1080/03088830902861086

Sanchez-Gonzalez, P. et al., 2019. Toward Digitalization of Maritime Transport, MDPI-Sensors. 19 (4):1-22.https://doi.org/10.3390/s19040926

Spekman, R.E. and Davis, E.W. 2004. Risky business: expanding the discussion on risk and the extended enterprise. International journal of physical distribution and logistics management. 34 5:414-433. https://doi.org/10.1108/09600030410545454

Samsul Islam. 2017. Empty truck trips problem at container terminals: A review of causes, benefits, constraints and solution approaches. Business Process Management Journal. 23(2):248-274. https://doi.org/10.1108/BPMJ-06-2015-0086

Tseng, Y-y, Yue, WL \& Taylor, MA 2005a. The role of transportation in logistics chain. Proceedings of the Eastern Asia Society for Transportation Studies. 5:1657-1672. Availbale at:

https://www.researchgate.net/publication/281230908_The_role_of_transportation_in_logistics_chain. Last accessed: 15/11/2020

Wang, Y., Caron, F., Vanthienen, J., Huang, L. and Guo, Y. 2014. acquiring logistics process intelligence: Methodology and an application for a Chinese bulk port. Expert Systems with Applications. 41(1):195-209. https://doi.org/10.1016/j.eswa.2013.07.021

Wilmsmeier, G, Monios, J \& Rodrigue, J-P. 2015. Drivers for Outside-In port hinterland integration in Latin America: The case of Veracruz, Mexico. Research in Transportation Business \& Management. 14:34-43. https://doi.org/10.1016/j.rtbm.2014.10.013 